\author{
St ud i P hiloso phic a \\ Wratis l avi e n s i a \\ vol. XVI, fasc. 3 (2021) \\ https://doi.org/10.19195/1895-8001.16.3.7
}

\author{
ŁUKASZ MŚCISŁAWSKI \\ ORCID: 0000-0003-0195-9064 \\ Politechnika Wrocławska
}

\title{
Między geniuszem, rewolucją i matematyką
}

\section{Between genius, revolution and mathematics}

\begin{abstract}
The book written by Wojciech Sady is an interesting and inspiring attempt to reconstruct the mechanism of the revolution that took place in physics at the beginning of the 20th century. As part of the attempts to characterize the process of the emergence of special relativity theory and the old quantum theory, author also raises the issue of the role of genius and imagination in the process of searching for new scientific theories. The work is based on rich factual material, however, has several weaknesses and - as it seems - several places that would not require greater precision. This work aims to identify these points.
\end{abstract}

Kewords: old quantum theory, special relativity theory, scientific revolution, genius, imagination, philosophy of science

Swego rodzaju sloganem stało się stwierdzenie, że u podstaw współczesnej fizyki leżą dwie teorie, które ukonstytuowały się mniej więcej w pierwszych dwóch dekadach XX wieku: teoria względności oraz mechanika kwantowa. Nie jest to stwierdzenie do końca precyzyjne, wskazuje jednak na doniosłość dla fizyki faktu pojawienia się wspomnianych teorii, choć nie tylko. Wydaje się zatem słuszne mówienie o rewolucji relatywistycznej i kwantowej, przynajmniej w odniesieniu do konsekwencji, jakie wywołało pojawienie się tych teorii nie tylko we wspomnianej dyscyplinie, lecz także jeśli chodzi o szeroko rozumiane implikacje filozoficzne.

Przedmiotem książki Wojciecha Sadego — przynajmniej w zamierzeniach — jest gruntowne studium jednego z centralnych zagadnień z zakresu filozofii nauki, a mianowicie pytania, w jaki sposób przebiega proces, który określa się mianem 
rewolucji naukowej. Centralnym zaś jej celem, jak deklaruje, jest próba odpowiedzi na pytanie: ,jak to jest możliwe, że uczeni zaczynają myśleć inaczej, niż ich myśleć nauczono"1. W swych analizach W. Sady wykorzystuje obfity materiał historyczny, a analizy filozoficzne przeprowadza - jak się wydaje - w nawiązaniu do głównych koncepcji zaproponowanych przez K.R. Poppera, T. Kuhna, I. Lakatosa oraz L. Flecka, najobficiej czerpiąc z dorobku tego ostatniego, zwłaszcza koncepcji kolektywów myślowych, procesu socjalizacji oraz źródeł nowych inspiracji naukowych w kolektywach myślowych ${ }^{2}$. W stosunku zaś do dwóch pierwszych (Poppera i Kuhna) zauważyć można na kartach książki daleko idącą polemikę.

Przebadany przez Sadego materiał historyczny jest imponujący, co stanowi niewątpliwy atut jego pracy. Można podzielić na dwie części, pierwszą związaną z ukształtowaniem się szczególnej teorii względności (rozdziały 1-4) oraz drugą, w ramach której prezentowany jest proces kształtowania się mechaniki kwantowej (rozdziały 5-7). Każdy etap prezentacji tego bogatego materiału jest wieńczony spostrzeżeniami metodologicznymi autora, które w jego zamierzeniach maja przekonać czytelnika do proponowanej odpowiedzi na wcześniej wspomniane, centralne pytanie.

Krótka i nieco uproszczona rekonstrukcja tej odpowiedzi byłaby następująca: źródłem czy zarzewiem potencjalnej rewolucji naukowej, są niespójności ${ }^{3}$ ujawniające się w zestawieniu wiedzy teoretycznej danego okresu z danymi doświadczalnymi. Zagadnienia, w których te niespójności ujawniają się ujawniają, stają się polem badawczym dla (relatywnie) młodych uczonych, którzy nie byli jeszcze tak związani praktyką naukową danej społeczności badaczy, by czuć się w obowiązku bardziej preferować klasyczny system zastanych praw niż obszar problematyczny. Oni to - jak sugeruje Sady, powodowani bliżej nieokreślonymi czynnikami, jak choćby młodzieńczą fantazją - wybierają ten właśnie obszar (anomalne fragmenty pasa ochronnego) jako podstawę własnych. Dzięki temu odnosili sukcesy w danej dziedzinie, które z kolei powodowały podejmowanie systematycznych badań, tym razem już przy użyciu nowych narzędzi teoretycznych ${ }^{4}$. Autor podkreśla tutaj znaczenie nieustannego rozwoju wiedzy w danej dyscyplinie, który to rozwój wiedzy wydaje się tutaj głównym motorem następujących mniej lub bardziej rewolucyjnych zmian. Próbuje się także rozprawić z dwoma mitami: mitem roli wyobraźni twórczej oraz mitem geniuszu (czy też w odniesieniu do konkretnych ludzi: geniuszy), który nie odgrywa wyjątkowej roli w całym rewolucyjnym procesie ${ }^{5}$. Propozycja wydaje się atrakcyjna i dobrze uargumentowana w oparciu o rozważany materiał. Czy jest tak rzeczywiście?

\footnotetext{
1 W. Sady, Struktura rewolucji relatywistycznej i kwantowej w fizyce, Kraków 2020, s. 26.

2 Nie są to oczywiście jedyne inspiracje W. Sadego — ich listę zamieszcza autor we Wstępie, por. ibidem, s. 15-17.

3 Przez niespójność Sady rozumie tutaj brak możliwości jednoczesnego zastosowania wszystkich znanych praw, wchodzących w skład wiedzy danego okresu, do opisu obszaru badanego przez daną dyscyplinę w tym okresie. Por. ibidem, s. 216.

4 Por. ibidem, s. 217-219.

5 Przykładowo w odniesieniu do roli wyobraźni ibidem, s. 31-34, 71-78, natomiast o geniuszu: ibidem, s. 219-220.
} 
Przede wszystkim Sademu nie można odmówić odwagi jeśli chodzi o prezentację własnej propozycji zmierzenia się z podejmowanym zagadnieniem. Nie jest to więc kolejny zbiór cytatów, lecz próba autentycznego poszukiwania rozwiązania problemu. Nawet jeśli czytelnik nie będzie podzielał jego wniosków czy nie uzna argumentacji za wystarczająco przekonującą, niewątpliwie będzie miał okazję do przemyślenia swojego własnego stanowiska w odniesieniu do omawianej kwestii struktury rewolucji naukowych. Pojawia się jednak kilka kwestii, które należałoby tutaj poruszyć, a które — być może — pomogą Sademu w udoskonaleniu pracy i może sprowokuja do napisania jej dalszego ciągu.

Pierwsza sprawa, na którą warto by zwrócić uwagę, dotyczy przedmiotu badań Sadego - a więc w jaki sposób doszło do radykalnej przebudowy obrazu świata i sposobu myślenia o nim wśród uczonych na skutek pojawienia się teorii względności i mechaniki kwantowej. Wydaje się, że zachodzi tutaj potrzeba większej precyzji. Krakowski filozof odnosi się bowiem do szczególnej teorii względności oraz do starej teorii kwantów ${ }^{6}$. Może wydawać się, że jest to zbędny szczegół, gdyby nie fakt, że Autor z niezrozumiałych powodów całkowicie pominął ogólną teorię względności, co sprawia wrażenie nieodróżniania obu tych teorii. Nie wspomniał też ani słowem o roli Minkowskiego rewolucji relatywistycznej (wprowadzenie koncepcji czasoprzestrzeni). Niemal strywializował też - a przynajmniej takie można odnieść wrażenie — proces formowania się mechaniki kwantowej jako ustabilizowanej teorii. Tej ostatniej kwestii dosłownie poświęca kilka stron? ${ }^{7}$. Wziąwszy pod uwagę, że mówiąc o rewolucji związanej z mechaniką kwantową, trzeba zauważyć, iż stara teoria kwantów stanowi do niej w pewnym sensie nieodłączne - ale jednak — preludium, zarówno jeśli zwróci się uwagę na zmianę obrazu świata, jak i radykalną zmianę relacji między obszarem rzeczywistości opisywanym przez tę teorię a środkiem opisu - czyli formalizmem matematycznym. Jest to zmiana, która jest zdecydowanie głębsza niż między modelami nierelatywistycznymi a relatywistycznymi ${ }^{8}$, i mówiąc o kwantowej rewolucji najczęściej, mówi się tak właśnie w odniesieniu do mechaniki kwantowej jako teorii przedstawionej przez Heisenberga, Pauliego, Jordana, Borna, Diraca i Schrödingera ${ }^{9}$. Wspomniany brak jakiejkolwiek wzmianki o ogólnej teorii względności oraz bardzo skrótowe odniesienie się do mechaniki kwantowej powoduje, że czytelnik może odnieść wrażenie, iż autor niejako zatrzymał się w połowie drogi. To wielka szkoda, gdyż wziąwszy pod uwagę historię powstawania obu tych teorii, mógłby znaleźć wzmocnienie niektórych swoich tez, zwłaszcza jeśli chodzi o rolę matematy-

6 Określenie stara teoria kwantów (w źródłach anglojęzycznych: old quantum theory) jest właściwym określeniem tego etapu, o którym wspomina autor. W polskiej literaturze przedmiotu można spotkać się niekiedy z określeniem pierwotna teoria kwantów — por. B. Średniawa, Mechanika kwantowa, Warszawa 1981, s. 3.

7 W. Sady, Struktura rewolucji relatywistycznej i kwantowej w fizyce, s. 203-207. Stwierdzenie, że rekonstrukcja procesu powstawania mechaniki kwantowej byłaby o wiele trudniejsza, jest niewątpliwie słuszne. Niestety nie osłabia to wrażenia strywializowania tego procesu przez autora, por. s. 219.

8 Kopczyński i Trautman mówią w tym przypadku o cięciu poglądowości, por. W. Kopczyński, A. Trautman, Czasoprzestrzeń i grawitacja, Warszawa 1984, s. 24.

${ }^{9}$ Dobre omówienie tego procesu stanowi klasyczne już dzieło M. Jammer, The Conceptual Development of Quantum Mechanics, New York 1966. 
ki w kształtowaniu się nowych teorii fizycznych ewentualnie skorygować inne swoje poglądy. W szczególności zaś proces kształtowania się ogólnej teorii względności mógłby nieco zmodyfikować spojrzenie na wzajemne oddziaływanie między wiedzą zastaną, danymi doświadczalnymi, oraz dobrze rozumianą twórczą wyobraźnią (jej temat zostanie jeszcze poruszony).

Druga kwestia odnosi się do kolejnych dwóch wątków, które Sady porusza w swojej pracy. Oba są z sobą ściśle związane, zostaną więc poruszone razem. Pierwszy z wątków dotyczy roli wyobraźni w procesie formowania się teorii naukowych (tutaj: w fizyce), drugi natomiast roli matematyki w tym procesie. Autor stwierdza:

nie da się wyprzedzić swego czasu, wypełnić luk w naszej wiedzy wytworami wyobraźni. W nauce należy postępować krok za krokiem — również, jak się poniżej okaże, w okresach rewolucyjnych a za każdym razem twierdzić tylko tyle, ile wynika z zastanej wiedzy i rezultatów eksperymentów ${ }^{10}$.

Pomijając apodyktyczno-normatywny charakter tej wypowiedzi, należy generalnie się z nim zgodzić. Wydaje się jednak, że użyteczne byłoby tutaj wprowadzenie pewnego rozróżnienia. Należałoby bowiem odróżnić wytwory fantazji (swobodnych jej wytworów) od specyficznie rozumianej wyobraźni, która wydaje się niezbędna przy uprawianiu danej dyscypliny, swego rodzaju wyczucie czy intuicja. Pojawia się tutaj pytanie, czy przez wiedzę zastaną Sady rozumie wiedzę dostępną tylko wewnątrz danej dyscypliny — w tym przypadku fizyki, czy także dyscyplin, z którymi dana dyscyplina jest powiązana (tutaj w grę wchodziłaby matematyka)? Zakładając, że zachodzi taka właśnie sytuacja, przytoczone stwierdzenie byłoby wysoce prawdopodobne $^{11}$. Wówczas wyobraźnia twórcza odnosiłaby się do umiejętności identyfikowania struktur matematycznych, przy pomocy których uczony chce opisywać zjawiska fizyczne. Tak długo, jak wyobraźnia „pracuje w tym duchu”, wydaje się, że można jej pozwolić na dowolne wzloty, ale nie fantazjowanie. Wydaje się, że trafnie ujął to S. Kalinowski — chodzi o to, żeby wyobraźnia dostarczyła pewnej idei organizującej całość wysiłku intelektualnego ${ }^{12}$. Niejednokrotnie podkreślana przez Sadego okoliczność, że tylko dostosowanie się do rygorystycznego prowadzenia przez struktury matematyczne dawała wyjście z kłopotliwych sytuacji ${ }^{13}$ jest znana, i w pełni znajduje swoje potwierdzenie w znanej wskazówce metodologicznej M. Hellera: „Fizyku teoretyku! Gdy masz inne poglądy niż twoje równania (potwierdzone zgodnością ich przewidywań z wynikami pomiarów), nie ruszaj równań, zmień poglądy!"14. Warto tutaj także zauważyć, co poniekąd wynika także z całości książki Sadego, że historia fizyki staje się niejako historią przystosowywania wyobraźni fizyków do posługiwania się coraz bardziej abstrakcyjnymi strukturami formalnymi. Stąd propozycja odróżnienia „swobodnego fantazjowania” od wyobraźni, która jest kształtowana przez matematykę. W tym miejscu warto jednak zwrócić uwagę, że niekiedy swoiste piękno i elegancja struktur matematycznych mogą być

10 W. Sady, Struktura rewolucji relatywistycznej i kwantowej w fizyce, s. 34.

11 Problematyczna byłaby sytuacja, gdy struktury matematyczne tworzy się niejako na bieżąco, a więc tworząc zręby wiedzy, której dotąd nie było.

12 S. Kalinowski, Nauka a fantazja, „Przegląd Naukowy i Pedagogiczny” 1 (1916), s. 15-28.

13 Por. przykładowo W. Sady, Struktura rewolucji relatywistycznej i kwantowej w fizyce, s. 71-79.

14 M. Heller, Einstein, Wszechświat i my, „Postępy Fizyki” 57 (2006), s. 113. 
zwodnicze. Ostatecznie fizyk tworzy teorię fizyczną i jeśli dana struktura matematyczna - niezależnie od swojego piękna - nie daje oczekiwanych rezultatów (predykcyjnych czy unifikujących), to dedukowanie kolejnych kroków przy jej pomocy może okazać się ślepą uliczką ${ }^{15}$.

W tym miejscu wypada też, jak się wydaje, zaproponować kolejne doprecyzowanie. Autor przeprowadza swego rodzaju demitologizację geniusza jako jednostki, która poniekąd na zasadzie creatio ex nihilo wprowadza zupełnie nowe teorie i jednocześnie zrywa pęta ustalonych, dotychczasowych schematów myślowych ${ }^{16}$. Taki naiwny obraz geniusza jest nie do utrzymania. Wydaje się jednak, że wymaga pewnego namysłu stwierdzenie, iż geniusz to ktoś, kto w danym stanie nauki podjął właściwe badania we właściwym czasie, wyposażony w odpowiednie zdolności matematyczne, pasję poznawczą i pragnienie uznania ${ }^{17}$. Czym innym jest jak się wydaje bycie sławnym (często także medialnie), a czym innym bycie geniuszem $\mathrm{w}$ danej dyscyplinie. Z jednej strony nie sposób się nie zgodzić ze stwierdzeniem, że geniusz to ktoś, kto podejmuje właściwe badania we właściwym czasie. Wydaje się jednak, że stwierdzenie to jest niewystarczające, wymaga bowiem dookreślenia co dokładnie należy rozumieć pod określeniem „właściwe badania”, a ponadto czy jest to jedyna cecha kogoś, kogo uważa się za geniusza? W tym kontekście warto się zastanowić nie tylko których uczonych fizycy wymieniliby jako geniuszy, ale a może przede wszystkim — jakimi kryteriami kierowaliby się przy tym wyborze.

Jak to się dzieje, że w tym, a nie innym okresie wskazano największą liczbę fizyków, których można by uznać za geniuszy? Jest to niewątpliwie interesujący problem badawczy - czy jest to tylko kwestia tego, że nie upłynęło jeszcze wystarczająco dużo czasu, a jednocześnie liczba prac współczesnych fizyków jest zbyt wielka, aby móc ocenić ich dorobek i wkład w rozwój nauki? A może w grę wchodzą tutaj jeszcze inne procesy? Może chodzi o to, że aby pojawiła się odpowiednia liczba fizyków, którzy będą potrafili wskazać właściwe kierunki rozwoju, potrzebna jest odpowiednia jakość ogólnie rozumianego zaplecza kulturalnego, jak zdaje się sugerować A. Staruszkiewicz? ${ }^{18}$

Sady zwraca także uwagę na niemalże determinującą rolę rozwoju wiedzy w zakresie danej dyscypliny, co pomniejsza niewątpliwie rolę genialnych uczonych. Stawia też pytanie: co by było, gdyby Einsteina nie było? ${ }^{19}$ Oczywiście pytanie to można rozciągnąć na innych uczonych, których powszechnie uważa się za genialnych, a w każdym razie takich, którzy wnieśli znaczący wkład w rozwój fizyki (bądź innej dyscypliny). Odpowiedź zapewne jest złożona. Z faktu, że problemy badawcze, na

15 Klasycznym przykładem wydaje się tutaj teoria strun, por. H. Kragh, Wielkie spekulacje. Teorie $i$ nieudane rewolucje $w$ fizyce $i$ kosmologii, Kraków, 2016, s. 523-581. Interesującym skądinąd faktem jest to, że ze złudnego powabu struktur matematycznych fizycy zdawali sobie sprawę już na początku XX wieku, a więc w okresie, którego dotyczy publikacja autora. Por. np. S. Kalinowski, $N a-$ uka a fantazja, s. 17-18.

16 W. Sady, Struktura rewolucji relatywistycznej i kwantowej w fizyce, s. 219.

17 Ibidem, s. 220.

18 A. Staruszkiewicz, Wspótczesny stan fizyki teoretycznej poważnym zagrożeniem cywilizacyjnym, „Foton” 74 (2001), s. 4-6.

${ }^{19}$ W. Sady, Struktura rewolucji relatywistycznej i kwantowej w fizyce, s. 120-121. 
skutek rozwoju fizyki, są podejmowane w wielu miejscach niezależnie (bądź niemal niezależenie), Sady wydaje się wyprowadzać wniosek (odwołując się przy tym do prawa wielkich liczb), że tak czy inaczej historia potoczyłaby się w sposób bardzo zbliżony $^{20}$. Wydaje się to wniosek dość dobrze uargumentowany ${ }^{21}$. Sam jednakże zauważa, że mamy do czynienia historią fizyki tak, jak się ona dokonała, nie mamy do zbadania historii alternatywnych. Warto tutaj jednak poczynić pewne spostrzeżenie, zwłaszcza w kontekście uwag o możliwościach pojawiania się (niezależnie) formalnie identycznych rozwiązań ważnych problemów fizycznych ${ }^{22}$. Problemem, na gruncie fizyki, nie jest pojawienie się rozwiązania formalnego. Trudność polega na tym, że rozwiązanie formalne potrzebuje jeszcze interpretacji fizycznej, czyli odpowiedniego powiązania wyrażeń matematycznych z wielkościami fizycznymi (mierzalnymi) ${ }^{23}$. Wydaje się więc, że ilość rozwiązań formalnych, występujących mniej więcej w tym samym czasie, nie jest jeszcze wystarczającym uzasadnieniem, aby odnośnie do możliwej, alternatywnej historii fizyki stwierdzać coś z absolutną stanowczością. W tym kontekście jest wrażenie swego rodzaju „wiedzotwórczego determinizmu”, niemal apodyktycznie sugerowana przez Sadego prawie od pierwszych stron książ$\mathrm{ki}^{24}$. Zasadnicza idea ciągłości rozwoju wiedzy wydaje się nie budzić większych zastrzeżeń tym bardziej, że rola ciągłego rozwoju wiedzy, bez kuhnowskich rewolucji, ale z jakościowymi zmianami, jest znana, czego przykładem mogą być analizy prac P. Duhema, przeprowadzone przez K. Szlachcica ${ }^{25}$. Brak jakiejkolwiek wzmianki o poglądach francuskiego fizyka w tym zakresie jest tu co najmniej zastanawiajaccy, tym bardziej, że analogiczne podejście, czyli wzięcie pod uwagę ciągłości rozwoju fizyki - a więc podkreślenie roli stanów pośrednich między wielkimi odkryciami - jest metodą zastosowaną przez samego autora, który jednocześnie właśnie w zaniedbaniu takiego podejścia widzi zasadniczy błąd Kuhna ${ }^{26}$.

Nieco problematyczny i niedookreślony jest tutaj wątek powiązania przez Sadego jakości rozwoju nauki z liberalnac demokracjac. Ma miejsce tutaj pewna trudność, gdyż Autor nie precyzuje, jak rozumie ten ustrój, natomiast stwierdzenia o jego dobroczynnym wpływie wydają się mieć charakter apodyktyczny ${ }^{27}$. Nie wiadomo także, co miałoby znaczyć określenie, że stosunek uczonych do otoczenia

20 Ibidem, s. 120-121 oraz s. 213.

21 Wypada tutaj zaznaczyć, że nie jest on tutaj jedynym. Por. w tej sprawie K. Szlachcic, Czy istnieje trzecia droga? Między racjonalnymi a socjologicznymi rekonstrukcjami rozwoju wiedzy, ,Annales Univeristatis Mariae Curie-Skłodowska" 35 (2010), s. 238.

22 Tego typu sytuację można wskazać w ramach historii ogłoszenia przez Einsteina szczególnej teorii względności, gdy analogiczną propozycję przedstawił także Poincaré.

23 Por. M. Heller, Einstein, Wszechświat i my, s. 109. Tego, przynajmniej pośrednio, dotyczy także kwestia postrzegania kogoś jako geniusza, przynajmniej w zakresie fizyki. Nie wystarczy tutaj sama właściwa praca badawcza we właściwym czasie - chyba że pracę badawczą rozumie się bardzo szeroko. Potrzebne byłoby tutaj przynajmniej kilka słów komentarza ze strony autora Struktury rewolucji relatywistycznej i kwantowej $w$ fizyce.

24 Por. W. Sady, Struktura rewolucji relatywistycznej $i$ kwantowej $w$ fizyce, s. 26.

25 K. Szlachcic, Czy istnieje trzecia droga?, s. 235-240. Praca Szlachcica zawiera także ciekawe zestawienie niektórych tez Sadego (zwłaszcza o nieczynieniu przez uczonych hipotez), które znalazły się także w Strukturze rewolucji relatywistycznej $i$ kwantowej w fizyce.

26 Por. W. Sady, Struktura rewolucji relatywistycznej $i$ kwantowej $w$ fizyce, s. 13.

27 Ibidem, s. 20-21. Określenie to wymagałoby jakiegoś wytłumaczenia. 
środowiska naukowego jest liberalno-demokratyczny ${ }^{28}$. Co najmniej wątpliwe są pochwały liberalnej demokracji w kontekście opisywanych prac, tym bardziej że żadne z opisywanych odkryć ani żaden z uczonych, o których mowa w książce, nie tworzył w takich warunkach. Stwierdzenie, że nie jest przypadkiem, że pojawienie się Principiów Newtona i Drugiego traktatu o rzadzie Locka przypadło na ten sam okres $^{29}$ nie wydaje się dobrym argumentem przemawiającym za liberalną demokracją jako optymalnym środowiskiem dla rozwoju nauki, gdyż akurat nie taki ustrój społeczny panował pod koniec XVII wieku w Królestwie Brytyjskim. Analogicznie, można poddać w wątpliwość tę tezę w przypadku Plancka, Einsteina czy Bohra (chodzi o ustrój społeczny, w którym funkcjonowali). Można się jednak zgodzić, że potrzebna jest pewna swoboda intelektualna oraz pewien dobrostan danej wspólnoty (społeczeństwa, państwa), aby stan dyscypliny mógł ulec zasadniczej przemianie (przez analogię do, przykładowo, dziejów filozofii i nauki w starożytnej Grecji ${ }^{30}$ ). Być może zatem chodzi nie tyle o ten konkretny ustrój społeczny, ile o wytworzenie pewnej jakości kultury (środowiska), wewnątrz której funkcjonują uczeni?

Podobne wrażenie sprawiają czynione, dość nieprecyzyjne, a jednocześnie mocne spostrzeżenia odnośnie relacji społecznych i ich wpływu (pozytywnego bądź negatywnego), jaki relacje te mają na funkcjonowanie znaczących dla rozwoju fizyki uczonych. Dość niefrasobliwe jest zestawianie z sobą nazizmu i przywiązania do ojczyzny, jak to czyni Sady w przypadku Lenarda ${ }^{31}$. Te dwie postawy nie sa jednak tożsame. Podobnie zastanawiające jest stwierdzenie, że: „postępowi nauk sprzyjają systemy liberalnej demokracji i poczucie bycia obywatelem świata, a nie małej czy dużej ojczyzny"32. Jest to przykład z jednej strony apologii liberalnej demokracji (o której już wspomniano), z drugiej strony stwierdzenie prawdziwe w najlepszym razie tylko częściowo prawdziwe. W jakim stopniu poczucie bycia obywatelem świata miało wpływ na uprawianie przez Einsteina nauki, czyli sztandarowy przykład w pracy Sadego ${ }^{33}$, tego nie wiadomo. Powstaja jednak tezy te wydają się zupełnie nie mieć zastosowania w odniesieniu do innych wielkich fizyki — Bohra, a w szczególności Heisenberga.

Wydaje się też, że dość apodyktyczny charakter niektórych stwierdzeń Sadego nieco zaciemnia prezentację niektórych zagadnień. Dobrym przykładem jest fragment, w którym rekonstruuje on sposób, w jaki Coulomb doszedł do zależności wartości siły elektrostatycznej od odległości między ładunkami i ich wartościami. Po pierwsze, zauważa, że nie jesteśmy w stanie zrekonstruować dokładnie przebiegu myśli Coulomba. Rekonstrukcja całości rozumowania nie wydaje się budzić zastrzeżeń, a autor prowadzi czytelnika do wniosku, że rozumowanie Coulomba było w swej istocie dedukcyjne. Stwierdza przy tym, że teza o niedookreśleniu teorii przez

28 Ibidem, s. 20

29 Ibidem, s. 21.

30 Ciekawe spostrzeżenia na temat powiązania podziału pracy i możliwości rozwoju czystej nauki i zastosowań technicznych w starożytnej Grecji przedstawia L. Russo, Zapomniana rewolucja. Grecka myśl naukowa a nauka nowoczesna, tłum. I. Kania, Kraków 2005, s. 216-222.

31 W. Sady, Struktura rewolucji relatywistycznej i kwantowej w fizyce, s. 154.

32 Ibidem.

33 Ibidem, s. 117 
dane nie ma tutaj zastosowania, a jeśli już — to dałoby się ją odrzucić na podstawie tego, co Coulombowi się narzucało ${ }^{34}$. Obrona tezy o niedookreśloności teorii przez dane może jednak — jak zauważa Sady — być tutaj uzasadniana przez fakt, że przez dowolny zbiór punktów można przeprowadzić dowolnie wiele krzywych. Stąd pytanie, dlaczego Coulomb wybrał akurat zależność odwrotnie proporcjonalną do kwadratu odległości? Odpowiedź Sadego jest następująca: wybrał najprostszą kr z y w ą ${ }^{35}$. Pojawia się tutaj trudność, gdyż jeśli jest to wybór, to wówczas pojawia się zastrzeżenie, co do dedukcyjnego charakteru całości rozumowania. Brakuje tutaj bardziej subtelnej rekonstrukcji połączenia elementu formalnego z danymi doświadczalnymi, zgromadzonymi przez Coulomba. Kwestią poboczną jest stwierdzenie Sadego, że według Poincarégo kryterium byłoby tu piękno, a według niego — prostota (najprostsza krzywa). Problem polega na tym, że jednym z kryteriów wyboru odpowiednich struktur formalnych u Poincarégo jest — oprócz piękna — także prostota.

Wszystkie powyższe spostrzeżenia bynajmniej nie podważają początkowego spostrzeżenia, że książka W. Sadego jest z pewnością godna polecenia i stanowi ciekawą propozycję spojrzenia na rewolucje naukowe. Jeśli chodzi o warstwę historyczną, to pozostaje życzyć sobie, aby inne prezentacje zagadnień z historii fizyki były równie interesujace.

Jest też rzeczą oczywistą, że w żadnej pracy nie da się uwzględnić wszystkiego — tym bardziej, że liczba literatury powstającej codziennie jest zatrważająca, a jej przeszukiwanie i studiowanie już dawno przerosło możliwości jednego człowieka. Nie dziwi zatem, że Sady nie zdołał uwzględnić wszystkiego.

W odniesieniu do zawartości filozoficznej, historycznej i fizycznej - gdyby autor zechciał ją przedyskutować wcześniej w ramach jakiegoś interdyscyplinarnego seminarium, byłaby to pozycja niewątpliwie zdecydowanie lepsza. Należy się jednak liczyć z tym, że prawdopodobnie jej objętość znacznie by się wówczas zwiększyła. Pozostaje zatem czekać na drugie wydanie pracy oraz - jeśli okazałoby się to możliwe - na część drugą, poświęconą ogólnej teorii względności i mechanice kwantowej.

Trzeba jeszcze podkreślić, że czytelnik niewątpliwie będzie miał okazję do odbioru całkiem sporej ilości inspiracji do przemyślenia własnych poglądów w poruszanych kwestiach, niezależnie od tego, czy ostatecznie zgodzi się ze wszystkimi sugestiami Sadego, czy nie, czy przekona go sposób argumentacji, czy nie do końca da się przekonać.

\section{Bibliografia}

Heller M., Einstein, Wszechświat i my, „Postępy Fizyki” 57 (2006), s. 108-113.

Jammer M., The Conceptual Development of Quantum Mechanics, New York 1966.

Kalinowski S., Nauka a fantazja, „Przegląd Naukowy i Pedagogiczny” 1 (1916), s. 16-28. Kopczyński W., Trautman A., Czasoprzestrzeń i grawitacja, Warszawa 1984.

Kragh H., Wielkie spekulacje. Teorie $i$ nieudane rewolucje $w$ fizyce $i$ kosmologii, Kraków 2016.

\footnotetext{
34 Ibidem, s. 32-33.

35 Ibidem.
} 
Russo L., Zapomniana rewolucja. Grecka myśl naukowa a nauka nowoczesna, tłum. I. Kania, Kraków 2005.

Sady W., Struktura rewolucji relatywistycznej i kwantowej w fizyce, Kraków 2020.

Staruszkiewicz A., Wspótczesny stan fizyki teoretycznej poważnym zagrożeniem cywilizacyjnym, „Foton” 74 (2001), s. 4-6.

Szlachcic K., Czy istnieje trzecia droga? Miedzy racjonalnymi a socjologicznymi rekonstrukcjami rozwoju wiedzy, „Annales Univeristatis Mariae Curie-Skłodowska” 35 (2010), s. 223-249. 
Studia Philosophica Wratislaviensia vol. XVI, fasc. 3, 2021 (C) for this edition by CNS 